\title{
Demam pada Penggunaan Analgesia Persalinan Epidural
}

\author{
Alfan Mahdi Nugroho ${ }^{1}$, Annemarie Chrysantia Melati ${ }^{1}$, Yusmein Uyun ${ }^{2}$ \\ ${ }^{1}$ Departemen Anestesiologi dan Terapi Intensif Fakultas Kedokteran Universitas Indonesia \\ RSUPN Cipto Mangunkusumo - Jakarta, ${ }^{2}$ Departemen Anestesiologi \& Terapi Intensif Fakultas Kedokteran \\ Kesehatan Masyarakat dan Keperawatan Universitas Gadjah Mada/ RSUP Dr Sardjito Yogyakarta
}

\begin{abstract}
Abstrak
Analgesia epidural telah diperkenalkan secara rutin sebagai salah satu modalitas analgesia pada proses persalinan sejak lama. Hubungan antara analgesia epidural persalinan dengan demam intrapartum pada maternal sudah disebutkan pada beberapa literatur. Demam didefinisikan sebagai peningkatan suhu tubuh lebih dari $38^{\circ} \mathrm{C}$ yang didapat dari dua kali pemeriksaan. Beberapa teori yang disebutkan antara lain perubahan termoregulasi, infeksi pada ibu-janin dan inflamasi non-infeksi yang dimediasi oleh sitokin proinflamasi. Namun demikian berbagai mekanisme analgesia epidural dapat menyebabkan demam masih terus diteliti. Identifikasi demam pada ibu saat persalinan merupakan hal yang penting untuk dilakukan karena memiliki konsekuensi klinis pada ibu dan neonatus. Pada ibu ditemukan suhu yang meningkat dikaitkan dengan peningkatan denyut jantung ibu, curah jantung, konsumsi oksigen, dan produksi katekolamin. Sedangkan pada janin demam intrapartum dapat menyebabkan sepsis, perubahan skor APGAR, peningkatan kebutuhan bantuan napas dan kejadian kejang. Efek demam pada ibu dan janin masih terus dipelajari, sehingga suatu saat didapatkan cara pencegahan yang paling baik yang pada akhirnya menghindarkan keraguan untuk melakukan analgesia persalinan.
\end{abstract}

Kata kunci: analgesia epidural; demam; persalinan

\section{Fever during labour epidural analgesia}

\begin{abstract}
Epidural analgesia has been routinely introduced as one of the analgesia modalities during labour. Literature has mentioned the relationship between epidural analgesia and intrapartum fever among mothers. Fever is defined as increased temperature above $38^{\circ} \mathrm{C}$ in more than two measurements. Several theories have been proposed, inculing thermoregulation changes, mother-fetal infection, and non-infectious inflammation mediated by proinflammatory cytokines. However, these mechanisms have been continued to evolve. Fever identification in pregnant women is essential to recognize clinical consequences to both mothers and neonates. Increased temperature in mothers is associated with increased heart rate, cardiac output, oxygen consumption, and catecholamines production. Meanwhile, in neonates intrapartum fever is related to sepsis, APGAR score changes, the need of respiratory support and incidence of neonatal seizure. Therefore, these consequences are extensively studied in order to determine the appropriate prevention.
\end{abstract}

Key words: epidural analgesia; fever; labour 


\section{Pendahuluan}

Hubungan antara analgesia epidural persalinan dengan demam intrapartum pada maternal pertama kali disebutkan pada tahun 1987 oleh Laure dan diperkuat oleh Fusi tahun 1989. ${ }^{1}$ Demam yang terjadi saat persalinan sering dikaitkan dengan luaran bayi yang tidak baik dan terhambatnya proses persalinan itu sendiri. Pada proses persalinan, meningkatnya kejadian instrumentasi dan seksio sesarea dikatakan merupakan salah satu efek akibat demam saat persalinan. $^{2}$ Sedangkan pada neonatus, peningkatan kejadian kejang, penurunan nilai APGAR, dan pemberian bantuan napas pada neonates, dikatakan berhubungan dengan terjadinya demam saat persalinan. ${ }^{3,4}$ Dari beberapa studi yang dilakukan, insiden hubungan analgesia persalinan epidural dengan demam intrapartum berkisar antara 10-34\%. ${ }^{5}$ Analgesia epidural telah diperkenalkan secara rutin sebagai salah satu modalitas analgesia pada proses persalinan sejak tahun $1946 .{ }^{6}$ Saat ini penggunaan analgesia epidural dengan obat anestetik lokal dosis rendah berhasil menurunkan insiden instrumentasi dan bedah sesar dibandingkan dengan penelitian terdahulu. Konsentrasi obat anestetik lokal yang rendah dibuktikan dapat memberikan analgesia yang cukup baik tanpa memberikan blok motorik yang dapat mempengaruhi proses persalinan. ${ }^{6}$

Etiologi hipertermia terkait epidural persalinan masih terus diteliti. Beberapa teori yang disebutkan antara lain perubahan termoregulasi, infeksi pada ibu-janin dan inflamasi non-infeksi yang dimediasi oleh sitokin proinflamasi. Namun demikian berbagai mekanisme epidural dapat menyebabkan demam masih terus diteliti. Karena dampak yang terjadi dapat menimbulkan perdebatan maka sangat penting bagi ahli anestesia, ahli neonatologi dan ahli kandungan untuk memahami dan mengelola demam ibu yang terkait dengan analgesia epidural.

\section{Peningkatan Suhu Maternal}

Sebelum membahas demam pada analgesia persalinan, tulisan ini akan membahas kemungkinan terjadinya peningkatan secara fisiologis suhu tubuh ibu saat persalinan. Pada proses persalinan, suhu ibu dipantau setiap saat bersamaan dengan tanda vital yang lain. Terdapat beberapa cara pengukuran suhu tubuh baik invasif maupun non-invasif, dan masing-masing mempunyai kelebihan dan kekurangan. Selama ini pengukuran suhu aksila dikatakan paling popular dilakukan oleh para praktisi medis. Pengukuran suhu kulit di daerah ini mudah digunakan namun memberikan gambaran suhu yang lebih rendah sekitar $1-2{ }^{\circ} \mathrm{C}$ dibandingkan suhu inti. Penempatan probe harus tepat pada arteri aksilaris dan posisi lengan berada melekat pada sisi badan untuk menghasilkan pengukuran yang akurat. ${ }^{7}$ Beberapa penelitian mengemukakan bahwa pengukuran suhu tubuh melalui mulut memberikan hasil yang baik dan juga mudah digunakan. Namun kekurangan metode ini adalah terjadinya pengaruh oleh frekuensi dan pola napas, makanan yang dikonsumsi dan suhu kepala. Banerjee dkk mempelajari monitor non-invasif terbaik untuk merefleksikan suhu dalam rahim. Mereka melibatkan 18 pasien dan mengukur secara simultan setiap 10 detik suhu dalam rahim, timpani, dan suhu permukaan kulit kaki dan abdomen. Selain itu mereka juga mengukur suhu oral setiap jam selama persalinan. Pengukuran suhu mulut dikatakan memiliki korelasi terbaik dengan suhu uterus. Ratarata, temperatur mulut suhu dalam rahim yang sedikit lebih rendah 0,8 C. ${ }^{8}$ Selain pengukuran suhu aksila dan oral, suhu timpani juga dapat digunakan untuk merefleksikan suhu rahim dengan baik. Pengukuran dapat dilakukan dengan dua metode yaitu kontak dan nonkontak. Metode kontak memberikan tingkat kesalahan yang lebih kecil namun memberikan risiko terjadinya perforasi membran timpani. Yang paling popular adalah metode nonkontak dengan menggunakan infra merah. Metode ini mudah digunakan namun kesalahan dapat terjadi karena kesalahan dalam penempatan posisi dan pengaruh serumen dalam liang telinga. ${ }^{9}$

Secara umum, demam didefinisikan sebagai peningkatan suhu tubuh lebih dari $38{ }^{\circ} \mathrm{C}$ yang didapat dari dua kali pemeriksaan. Terdapat beberapa penelitian yang mencoba menggambarkan terjadinya peningkatan suhu secara fisiologis saat persalinan. Pada tahun 
1987, Acker dkk. mempelajari suhu maternal dan menemukan bahwa suhu maternal tanpa penggunaan analgesia persalinan berkisar antara 34,6 sampai $37,6{ }^{\circ} \mathrm{C}$ sesuai dengan variasi diurnal. ${ }^{10}$

Demikian pula melakukan penelitian pada 189 pasien hamil aterm yang mendapat antibiotik profilaksis dan tidak. Mereka menemukan bahwa persalinan tidak secara signifikan meningkatkan suhu tubuh normal dan menggambarkan suhu maternal rata-rata $37{ }^{\circ} \mathrm{C} \pm 0.42{ }^{\circ} \mathrm{C}$ selama persalinan. ${ }^{11}$ Pendapat yang berbeda disampaikan oleh Froelich dkk pada tahun 2012. Mereka menemukan kecenderungan kenaikan suhu yang signifikan pada wanita saat persalinan tanpa tanda-tanda infeksi. Namun peningkatan suhu banyak dipengaruhi oleh kejadian ketuban pecah dini dan peningkatan Indeks Massa Tubuh (IMT). ${ }^{12}$

\section{Demam pada Analgesia Persalinan Epidural}

Identifikasi demam pada ibu saat persalinan merupakan hal yang penting untuk dilakukan karena memiliki konsekuensi klinis pada ibu dan neonatus. Banyak penelitian yang menggunakan kontrol maupun tidak yang mencoba membuktikan adanya demam pada penggunaan epidural analgesia persalinan. Penelitian yang mendukung adanya korelasi antara penggunaan analgesia epidural dan demam saat persalinan dan sebagian lagi tidak mendapatkan hubungan yang signifikan. Fusi dkk tahun 1989 merupakan peneliti yang pertama melakukan analisa tentang demam saat persalinan dengan membandingkan pasien yang mendapat meperidin intravena dan analgesia epidural. Pasien yang mendapat meperidin memperlihatkan grafik suhu yang relatif tetap dibandingkan yang menggunakan analgesia epidural dimana terjadi peningkatan suhu terutama setelah penggunaan epidural selama 6 jam. ${ }^{13}$ Camann dkk melakukan pengukuran suhu oral dan membran timpani pada 53 wanita saat persalinan. Tiga kelompok yang diukur mendapatkan analgesia menggunakan nalbufin intravena dan analgesia epidural bupivakain dengan atau tanpa fentanil. Para peneliti tidak menemukan perbedaan suhu ibu di antara semua kelompok selama 4 jam pertama. Pada jam ke-5, suhu rata-rata membran timpani secara signifikan lebih tinggi pada kelompok epidural bila dibandingkan dengan kelompok nalbuphine. ${ }^{14}$ Macaulay dkk melakukan pengukuran pada suhu kulit janin, suhu dinding rahim ibu dan suhu mulut pada 57 wanita saat persalinan. Dari penelitian ini didapatkan analgesia epidural menghasilkan peningkatan suhu janin yang signifikan dibandingkan dengan metode analgesia lainnya. Durasi analgesia epidural berkorelasi dengan suhu. ${ }^{15}$ Faktor-faktor selain penggunaan analgesia epidural yang memicu peningkatan suhu saat persalinan juga dikemukakan oleh beberapa penelitian. Herbst dkk melakukan studi kasus kontrol retrospektif dan studi berpasangan terhadap 3109 pasien. Hasilnya 61,1\% pasien dengan analgesia epidural mengalami demam dibandingkan $21 \%$ yang mempunyai suhu normal. Dalam studi tersebut, nulipara dan durasi persalinan yang lama dikaitkan dengan risiko peningkatan suhu. Dari hasil penelitian tersebut disimpulkan bahwa penggunaan analgesia epidural, lama persalinan dan ketuban pecah dini merupakan factor independen yang berkaitan dengan demam intra partum. ${ }^{16}$ Phillip J dkk melakukan penelitian pada 715 pasien yang mendapat analgesia persalinan dengan epidural bupivakain dan fentanil dibandingkan dengan meperidin intravena.

Dari hasil penelitian tersebut didapatkan bahwa analgesia epidural merupakan salah satu penyebab demam intra artum. Nullipara dan persalinan yang memanjang juga merupakan faktor yang berkontribusi pada kejadian demam. ${ }^{17}$ Hubungan antara tingkat demam yang terjadi dengan lamanya pemakaian analgesia epidural juga sudah dinyatakan oleh penelitian yang dilakukan oleh Vinson dkk tahun 1993, mereka melakukan penelitian kombinasi retrospektif pada status pasien dalam persalinan, prospektif kohort observasional dan penelitian case control pada neonates yang mengalami demam saat lahir. Mereka menyimpulkan bahwa penggunaan analgesia epidural berkaitan dengan kejadian demam dan tingkat kenaikan suhu berkaitan dengan seberapa lama analgesia epidural tersebut digunakan. ${ }^{18}$ 


\section{Mekanisme Demam pada Persalinan}

Mekanisme peningkatan suhu ibu saat persalinan dengan analgesia epidural masih tetap kontroversial, namun beberapa hal yang sampai saat ini diduga menjadi penyebab demam intrapartum. Beberapa teori telah dikemukakan, termasuk (1) perubahan dalam termoregulasi, (2) infeksi dan (3) inflamasi.

\section{Perubahan Pengaturan Suhu (Termoregulasi)}

Proses persalinan merupakan proses fisik yang bersifat termogenik atau menimbulkan panas karena peningkatan konsumsi oksigen akibat kontraksi otot uterus dan skeletal. Hipotalamus kemudian memicu proses seperti vasodilatasi, keringat, dan hiperventilasi untuk meningkatkan kehilangan panas. Analgesia epidural dikatakan dapat menyebabkan ketidakseimbangan antara produksi panas dan mekanisme hilangnya panas. ${ }^{13}$ Secara umum, analgesia epidural menyebabkan penurunan suhu inti akibat redistribusi panas tubuh dari inti ke perifer yang pada akhirnya meningkatkan pembuangan panas oleh tubuh. ${ }^{19}$ Efek ini kemudian diimbangi oleh analgesia epidural yang menurunkan ambang termoregulatori menggigil dengan menghalangi masukan aferen dingin dari bagian anestesi tubuh. Akibatnya pasien akan menggigil untuk meningkatkan produksi panas. Gleeson dkk tahun 1989 menemukan bahwa demam terjadi 2 kali lebih sering pada wanita yang menggigil dibandingkan dengan mereka yang tidak setelah pemasangan epidural. ${ }^{20}$ Pengeluaran keringat merupakan salah satu respon tubuh untuk menurunkan suhu tubuh. Sympathectomy dari analgesia epidural akan menghambat terjadinya hal ini. Blok epidural mengubah respon termoregulasi terhadap pembentukan panas dengan meningkatkan ambang berkeringat. Dalam hal ini epidural dikatakan dapat menghalangi keluarnya keringat pada segmen tubuh yang mendapat epidural sehingga suhu tubuh meningkat. ${ }^{21}$ Pasien yang tidak menerima analgesia selama persalinan juga cenderung mengalami hiperventilasi. Hal ini bersama dengan pengeluaran keringat akan menurunkan suhu tubuh pasien. Dengan memberikan analgesia yang efektif, seperti analgesia epidural tingkat hiperventilasi dan kehilangan panas akan berkurang dan suhu tubuh akan meningkat. ${ }^{15}$

\section{Infeksi}

Infeksi dikatakan sebagai penyebab paling umum kenaikan suhu atau demam ibu dalam persalinan. Salah satu infeksi yang paling banyak terjadi saat persalinan adalah korioamnionitis yaitu infeksi cairan amnion, membran, plasenta, dan/ atau desidua walaupun tidak memungkinkan terjadinya infeksi lain seperti infeksi saluran kemih dan infeksi saluran pernapasan. Dashe dkk mempelajari hubungan antara inflamasi plasenta dan demam ibu. Wanita dengan analgesia epidural dikatakan memiliki durasi persalinan yang lebih lama sehingga akan meningkatkan kejadian demam pada pasien yang telah mengalami pecah ketuban sebelumnya. Penelitian ini menyimpulkan bahwa hubungan antara analgesia epidural dengan demam ibu hanya terjadi pada pasien dengan korioamnionitis sebelumnya, sehingga demam merupakan akibat dari infeksi dan bukan analgesia itu sendiri. Kelemahan pada penelitian ini adalah mereka tidak melakukan analisa kultur pada plasenta untuk membuktikan adanya infeksi. ${ }^{22}$ Penelitian selanjutnya dilakukan oleh Vallejo dkk tahun 2001 yang melakukan analisa pada 14.073 data pasien selama periode dua tahun. Penelitian ini membagi pasien dalam 3 kelompok (1) parturien dengan korioamnionitis klinis tanpa analgesia epidural, (2) parturien dengan korioamnionitis yang menggunakan analgesia epidural, dan (3) parturien yang menggunakan analgesia epidural namu tidak ada bukti adanya infeksi. Insiden demam pada pasien dengan korioamnionitis tanpa menggunakan analgesia epidural (kelompok 1) adalah $100 \%$. Pasien dengan analgesia epidural dan korioamnionitis (kelompok 2) juga mengalami demam $100 \%$. Pasien dengan analgesia epidural dan tidak ada bukti korioamnionitis (kelompok 3) memiliki insidensi hanya $1 \%$. Dari penelitian ini disimpulkan bahwa analgesia epidural tanpa korioamnionitis tidak terkait dengan demam ibu, peningkatan tingkat persalinan operatif atau skor APGAR rendah. ${ }^{23}$ 
Berkaitan dengan infeksi sebenarnya terdapat beberapa penelitian yang mempunyai pendapat lain dari penelitian sebelumnya. Salah satunya adalah penelitian yang dilakukan oleh Sharma dkk tahun 2014. Mereka mencoba memberikan antibiotic profilaksis kepada 200 pasien saat persalinan dan dibandingkan dengan 200 pasien lain yang mendapat plasebo. Kedua kelompok mendapatkan analgesia epidural. Penelitian ini mendapatkan bahwa demam selama analgesia epidural dikaitkan dengan peradangan plasenta. Namun pemberian profilaksis antibiotik tetap tidak menurunkan kejadian demam maupun inflamasi. Hal ini menunjukkan bahwa infeksi tidak selalu menyebabkan demam selama persalinan dan penyebab lainnya harus tetap dipikirkan. ${ }^{24}$

\section{Inflamasi}

Beberapa literatur terkini menyebutkan peran proses inflamasi tanpa disertai infeksi pada ibu yang mengalami demam saat persalinan dengan menggunakan analgesia epidural. Dari hasil pengukuran kadar biomarker proinflamasi ibu dan janin dikatakan bahwa wanita yang mendapat analgesia epidural saat persalinan mempunyai nilai yang lebih tinggi dibanding yang tidak mendapat epidural. Smulian dkk melakukan pengukuran kadar IL-6 darah ibu dan darah tali pusat terhadap wanita yang demam saat persalinan menyatakan bahwa kadar serum IL-6 ibu adalah penanda kuat untuk demam intrapartum jangka panjang. Lemahnya hubungan antara respon inflamasi janin dan plasental menunjukkan kontribusi yang lebih kecil dari inflamasi intraamnion untuk demam intrapartum. ${ }^{25}$ Goetzl dkk melakukan penelitian secara prospektif pada wanita nulipara dengan analgesia epidural dengan penggunaan asetaminofen dibanding plasebo. Sampel diperoleh dari darah ibu dan darah tali pusat. Kejadian demam antara dua group tidak berbeda. Diperoleh kadar IL-6 pada ibu yang demam lebih tinggi dibanding pasien yang tidak demam. Selain itu, neonatus yang lahir dari ibu demam memiliki tingkat IL-6 yang juga lebih tinggi dan hasil kultur darah pada neonates menghasilkan hasil negatif pada semua sampel. Dari penelitian ini disimpulkan bahwa demam pada penggunaan epidural berhubungan dengan inflamasi pada ibu dan janin tanpa adanya infeksi neonatal. Kadar sitokin yang lebih tinggi dalam serum ibu menunjukkan bahwa kompartemen ibu adalah sumber peradangan primer. ${ }^{26}$ Riley dkk melakukan analisis terhadap kultur plasenta dan kadar sitokin saat masuk dan postpartum pada 200 wanita selama periode prenatal. Penelitian ini menyatakan bahwa perempuan yang menerima analgesia epidural mengalami demam lebih sering dibanding tidak menggunakan. Kejadian infeksi tidak berbeda bermakna antara dua kelompok tersebut. Pada saat persalinan, kadar IL-6 meningkat lebih tinggi pada pasien yang mendapat analgesia epidural dibanding tanpa epidural. Oleh karena itu dapat disimpukan bahwa demam berkaitan dengan penggunaan epidural analgesia dan hal tersebut tidak dipengaruhi oleh kejadian infeksi tetapi berhubungan dengan adanya inflamasi. ${ }^{27}$

Pada epidural analgesia, beberapa penelitian mencoba menganalisa apakah lama dan jenis penggunaan obat-obat anestesia baik anestetik lokal maupun ajuvan memiliki pengaruh terhadap kejadian demam. Mantha dkk membandingkan penggunaan epidural kontinyu (CLEA) dan intermiten (ILEA) dengan kejadian demam. Mereka mendapatkan insiden demam pada ILEA pada 4 jam pertama lebih rendah daripada CLEA. Pada 8 jam dan sesudahnya, tidak ada perbedaan yang signifikan. Insiden demam secara keseluruhan adalah tidak berbeda secara signifikan di antara kedua kelompok. ${ }^{28}$ Wang dkk mencoba membandingkan waktu pertama inisiasi epidural pada dua kelompok pasien yang mendapat kombinasi spinal epidural terhadap kejadian demam intrapartum. Kelompok pertama mendapat inisiasi epidural segera setelah mendapat analgesia spinal, sedangkan group kedua mendapat inisiasi lambat setelah pasien merasa sakit. Dari penelitian ini tidak didapatkan perbedaan bermakna antara dua kelompok terhadap kenaikan suhu yang terjadi pada ibu. ${ }^{29}$ Sebelumnya penggunaan opioid pada analgesia epidural dikatakan berhubungan dengan insidensi demam maternal yang lebih rendah. Namun penelitian yang dilakukan oleh Gross dkk mengatakan hal sebaliknya bahwa tidak ada perbedaan bermakna 
pada kejadian demam intraprtum antara pasien yang menggunakan opioid dan yang tidak. ${ }^{30}$

\section{Efek yang Ditimbulkan Akibat Demam}

\section{Efek pada Ibu}

Efek buruk yang ditimbulkan akibat demam pada persalinan menjadi kekhawatiran banyak pihak. Oleh karena itu banyak peneliti yang melakukan analisa terhadap dampak buruk yang mungkin terjadi akibat demam baik pada ibu maupun pada janin. Suhu yang meningkat dikaitkan dengan peningkatan denyut jantung ibu, curah jantung, konsumsi oksigen, dan produksi katekolamin. Apabila dikaitkan dengan perubahan anatomi dan fisiologi akibat kehamilan, maka kenaikan suhu tubuh ini akan memperberat perubahan yang sudah terjadi. Efek fisiologis ini jarang mengganggu kesehatan ibu yang sehat namun berpotensi mengganggu hemodinamik pasien dengan penyakit jantung atau paru berat. Pada proses persalinan, penelitian yang dilakukan oleh Lieberman dkk menyebutkan kejadian persalinan sesar dan instrumentasi yang meningkat dua kali lipat pada wanita nulipara dengan suhu yang meningkat selama persalinan. ${ }^{2}$ Pada demam intrapartum, pemakaian atibiotik juga meningkat seperti dinyatakan pada penelitian oleh Goetzl dkk yang melakukan analisa pemakaian antibiotik pada 1235 nulipara saat persalinan. ${ }^{30}$

\section{Efek pada Janin}

Dapat dikatakan bahwa hampir semua kejadian yang terjadi pada ibu, secara langsung atau tidak akanmempengaruhi kondisijanin.Efekdemamibu terhadap janin dan bayi baru lahir telah membawa kontroversi yang cukup besar. Suhu janin bergantung pada transfer panas dari ibu sehingga demam pada ibu bisa menghasilkan hipertermia janin. Beberapa efek samping yang terjadi akibat demam pada ibu telah didokumentasikan pada periode pascapartum. Sepsis pada neonatus merupakan salah satu efek yang mendapat perhatian besar. Tahun 1997 Lieberman dkk melakukan penelitian pada 1657 pasien dalam persalinan. Mereka menganalisa kejadian demam pada penggunaan analgesia epidural, neonatal sepsis dan penggunaan antibiotik. Di antara 1657 bayi, $25,1 \%$ diantaranya dievaluasi untuk kemungkinan terjadinya sepsis. Tingkat evaluasi untuk sepsis lebih tinggi pada kelompok epidural: $34,0 \%(\mathrm{n}=356)$, dibandingkan dengan $9,8 \%(\mathrm{n}=$ $60)$ pada kelompok tanpa epidural.

Goetzl dll melakukan penelitian pada 1109 wanita hamil yang tidak mengalami demam saat persalinan. Evaluasi sepsis neonatal dilakukan atas dasar adanya 1 kriteria mayor atau 2 kriteria minor. Kriteria mayor termasuk ruptur membran selama $>24$ jam atau denyut jantung janin $>160$ per menit. Kriteria minor termasuk suhu maternal $99,6^{\circ} \mathrm{F}$ hingga $100,4^{\circ} \mathrm{F}$, ketuban pecah selama 12 sampai 24 jam, sel darah putih $>15000$ sel / $\mathrm{mL} 3$, atau skor APGAR $<7$ pada menit ke 5 . Penelitian ini mendapatkan bahwa bayi yang lahir dari wanita yang tidak demam namun menggunakan anestesi epidural lebih banyak dievaluasi untuk sepsis dibandingkan bayi dari pasien tanpa epidural ( $20,4 \%$ vs $8,9 \%)$, meskipun kejadian sepsis tidak berbeda bermakna antara dua kelompok. Sehingga dapat disimpulkan bahwa analgesia epidural dikaitkan dengan peningkatan terjadinya kriteria mayor dan minor sepsis neonatus pada wanita tanpa demam.

Selain sepsis, perubahan skor APGAR, kebutuhan bantuan napas dan kejadian kejang juga dikemukakan oleh beberapa peneliti. Lieberman dkk melakukan penelitian terhadapa 1218 wanita. Mereka mendapatkan bahwa pada pasien dengan demam terjadi peningkatan kejadian denyut nadi janin rendah dan skor APGAR 1 menit kurang dari 7. Demam maternal yang lebih tinggi dikaitkan dengan kebutuhan bantuan ventilasi pada saat melahirkan dan kebutuhan akan oksigen tambahan saat perawatan. Demam juga dikaitkan dengan kejang neonatal walaupun kejadiannya tidak banyak. ${ }^{3}$ Pada penelitian lain yang dilakukan oleh Perlman dkk mereka menemukan bahwa demam intra partum meningkatkan kejadian skor APGAR 5 menit lebih rendah dan peningkatan kebutuhan resusitasi kardiopulmoner pada bayi. ${ }^{30}$

\section{Simpulan}

Hubungan antara analgesia epidural dengan terjadinya demam pada ibu saat persalinan masih menjadi perdebatan sampai saat ini 
seiring dengan mekanismenya yang masih belum diketahui secara jelas. Tiga mekanisme utama yang diketahui saat ini yaitu infeksi, inflamasi dan perubahan regulasi suhu masih menjadi dasar pemikiran banyak peneliti. Efek demam pada ibu dan janin masih terus dipelajari, sehingga suatu saat didapatkan cara pencegahan yang paling baik yang pada akhirnya menghindarkan ketakutan beberapa praktisi medis untuk melakukan analgesia persalinan.

\section{Daftar Pustaka}

1. Yancey MK, Zhang J, Schwarz J, Dietrich CS, Klebanoff M. Labor epidural analgesia and intrapartum maternal hyperthermia. Obstet Gynecol. 2001;98(5):763-70.

2. Lieberman E, Cohen A, Lang J, Frigoletto F, Goetzl L. Maternal intrapartum temperature elevation as a risk factor for cesarean delivery and assisted vaginal delivery. Am J Public Health. 1999;89(4):506-10.

3. Lieberman E, Lang J, Richardson DK, Frigoletto FD, Heffner LJ, Cohen A. Intrapartum maternal fever and neonatal outcome. Pediatrics. 2000;105(1 Pt 1):8-13.

4. Greenwell EA, Wyshak G, Ringer SA, Johnson LC, Rivkin MJ, Lieberman E. Intrapartum temperature elevation, epidural use, and adverse outcome in term infants. Obstet Gynecol Surv. 2012;67(5):275-7.

5. Chan JJI, Dabas R, Han RN, Sng BL. Fever during labour epidural analgesia. Trends Anaesth Crit Care. 2018;20:21-5.

6. Flett GG. Analgesia in labour: induction and maintenance. Anaesth Intensive Care Med. 2016;17(7):324-7.

7. Wartzek T, Mühlsteff J, Imhoff $M$. Temperature measurement. Biomed Tech Eng. 2011;56(5):241-57.

8. Banerjee S, Cashman P, Yentis SM, Steer PJ. Maternal temperature monitoring during labor: concordance and variability among monitoring sites. Obstet Gynecol. 2004;103(2):287-93.

9. Daanen H. Infrared tympanic temperature and ear canal morphology. J Med Eng Technol. 2006;30(4):224-34.

10. Acker DB, Schulman EB, Ransil BJ, Sachs BP, Friedman EA. The normal parturient's admission temperature. Am J Obstet Gynecol. 1987;157(2):308-11.

11. Bartholomew ML, Ashkin E, Schiffman A, Larsen JW. Maternal temperature variation during parturition. Obstet Gynecol. 2002;100(4):642-7.

12. Frölich MA, Esame A, Zhang $\mathrm{K}, \mathrm{Wu} \mathrm{J}$, Owen J. What factors affect intrapartum maternal temperature? A prospective cohort study: Maternal intrapartum temperature. Anesthesiology. 2012;117(2):302-8.

13. Fusi L SP, Beard RW, Maresh MJ, Beard RW. Maternal pyrexia associated with the use of epidural analgesia in labour. Lancet. 1989;1(8649):1250-2.

14. Camann WR, Hortvet LA, Hughes N, Bader AM, Datta S. Maternal temperature regulation during extradural analgesia for labour. Br J Anaesth. 1991;67(5):565-8.

15. Macaulay JH, Bond K, Steer PJ. Epidural analgesia in labor and fetal hyperthermia. Obstet Gynecol. 1992;80:665-9.

16. Herbst $A$, Wølner-Hanssen $P$, Ingemarsson I. Risk factors for fever in labor. Obstet Gynecol. 1995;86(5):790-4.

17. Phillip J, Alexander JM, Sharma SK, Leveno KJ, McIntire DD, Wiley J. Epidural analgesia during labor and maternal fever. Anesthesiol. 1999;90:1271-5.

18. Vinson DC, Thomas R, Kiser T. Association between epidural analgesia during labor and 
fever. J Fam Pract. 1993;36:617.

19. Matsukawa T, Sessler DI, Christensen R. Heat flow and distribution during epidural anesthesia. Anesthesiol. 1995;83:961-7.

20. Gleeson N, Nolan K, Ford M. Temperature, labour and epidural analgesia. Lancet 1989;861-2.

21. Glosten B, Savage M, Rooke GA, Brengelmann GL. Epidural anesthesia and the thermoregulatory responses to hyperthermia - preliminary observations in volunteer subjects. Acta Anaesthesiol Scand. 1998;442-6.

22. DasheDS, RogerBB,McintireDDLK.Epidural analgesia and intrapartum fever: placental findings. Obstet Gynecol. 1999;93(3):341-4.

23. Vallejo MC, Kaul B, Adler LJ, Phelps AL, Craven CM, Macpherson TA, et al. Chorioamnionitis, not epidural analgesia, is associated with maternal fever during labour. Can J Anesth. 2001;48(11):1122-6.

24. Sharma SK, Rogers BB, Alexander JM, McIntire DD, Leveno KJ. A Randomized trial of the effects of entibiotic prophylaxis on epidural-related fever in labor. Anesth analg. 2013;35(1):50-1.

25. Smulian JC, Bhandari V, Vintzileos AM, Shen-Schwarz S, Quashie C, Lai-Lin YL, et al. Intrapartum fever at term: Serum and histologic markers of inflammation. Am J Obstet Gynecol. 2003;188(1):269-74.

26. Goetzl L, Evans T, Rivers J, Suresh MS, Lieberman E. Elevated maternal and fetal serum interleukin-6 levels are associated with epidural fever. Am J Obstet Gynecol. 2002;187(4):834-8.

27. Riley LE, Celi AC, Onderdonk AB, Roberts DJ, Johnson LC, Tsen LC, et al. Association of epidural-related fever and noninfectious inflammation in term labor. Obstet Gynecol. 2011;117(3):588-95.

28. Mantha VR, Vallejo MC, Ramesh V, Jones BL, Ramanathan S. Maternal and cord serum cytokine changes with continuous and intermittent labor epidural analgesia: A randomized study. Sci World J. 2012;2012.

29. Wang LZ, Chang XY, Hu XX, Tang BL, Xia F. The effect on maternal temperature of delaying initiation of the epidural component of combined spinal-epidural analgesia for labor: A pilot study. Int $\mathrm{J}$ Obstet Anesth. 2011;20(4):312-7.

30. Gross JB, Choehn AP, Lang JM, Frigoletto FD, Lieberman ES. Differences in systemic opioid use do not explain increased fever incidence in parturients receiving epidural analgesia. Anesthesiol. 2002;97(1):157-61. 